\title{
The Effects of Political Cynicism and National Siege Mentality on the Internalization of an Anti-European Sentiment
}

\begin{abstract}
Zlatko Šram ${ }^{1}$
ABSTRACT

This paper aims to provide an insight into the political-psychological understanding of an attitudinal construct labeled anti-European sentiment. A structural equation model for prediction was developed and evaluated by using full information mximum likelihood estimates obtained from LISREL 8.52 computer program. Assumption was that both political cynicism and national siege mentality would have an effect on anti-European sentiment. The data reported here were obtained by standard survey methods on the sample of adult population in Croatia $(\mathrm{N}=533)$. Confirmatory factor analysis (CFA) was performed to explore factorial and construct validity of the measures used in this research. CFA yielded unidimensional construct measurements with acceptable fit indices. Structural model indicated that exogenous variables (political cynicism, national siege mentality) have significant effects on the anti-European sentiment used as an endogenous (dependent) variable. Goodness-of-fit indices suggested acceptable fit of the model (RMSEA=0.07, CFI=0.97, $\mathrm{NNFI}=0.97, \mathrm{SRMR}=0.05)$. Given the amount of variance of anti-European sentiment, it was showen that political cynicism and national siege mentality have strong predictive validity for anti-European sentiment (43 percent of the variance was explained by the structural model). In order to explain the interactions among the variables investigated, the author proposed the distrust-threat model of political hostility.
\end{abstract}

Keywords: Anti-European sentiment, distrust-threat model, political cynicism, siege mentality, uncertainty. Available Online: 22-02-2015

This is an open access article under Creative Commons Attribution 4.0 License, 2016.

\subsection{INTRODUCTION}

The European Union (EU) is not only an economic but also a security organization which is indivisible from the EU integrative dynamics (Glaurdić \& Vuković, 2015). The attitudes towards the EU as far as security needs are concerned are grounded in strongly divergent historical experiences of war and peace (Gabel \& Palmer, 1995), or in national and regional historical legacies influenced by national memories and contextual experiences of wars led in the region of former Yugoslavia in the gos last

\footnotetext{
${ }^{1}$ Institute for Migration and Ethnic Studies, 10000 Zagreb, Croatia, E-mail: zlatko.sram@imin.hr
} 
century. „This issue of the effects of different... historically rooted security preferences on the levels of support for the EU is particularly important when it comes to the postwar region of the Western Balkans" (Glaurdić \& Vuković, 2015, p. 2). In other words, the current problems confronting the integrity of the EU are not confined to the domain of economics but also can be threatened by political and cultural crisis (Hartleb, 2012). Such crisis are surely connected with the state sovereignty and national identity issues in the sense that nation-state sovereignty is being destroyed and national identities are being weakened. In this research we have not been primarily concerned with the economic cost/benefit calculations, war legacies in former Yugoslavia, the roles of political parties as the agencies in shaping anti-European sentiment (Glaurdić \& Vuković, 2015) and with the causes and reasons of political distrust in general and as a legacy of communist rule (Mishler \& Rose). Instead, we have primarily been concerned about the relations existing among the latent variables labeled political cynicism, national siege mentality, and anti-European sentiment, where the first two were the exogenous variables and the third was the endogenous (dependent) variable in the structural model. Taking into consideration political-psychological meaning of the three attitudinal latent variables (defined, analysed and explained below) we hypothesized that political cynicism and national siege mentality have significant effects on the internalization of an anti-European sentiment. We assumed that an anti-European sentiment is the component of a broader attitudinal construct underlying similar political cognitive and motivational processes. In line with Jost et al.'s (2009) theoretical approach to the structure and function of political orientations, Jost \& Napier's (2012) model of motivated social cognition, and Jost \& Napier's (2012) uncertainty-threat model of political conservatism, we have proposed a distrust-threat model of political hostility in explaining mutual relationships of political cynicism, siege mentality, and anti-European sentiment.

\section{ANTI-EUROPEAN SENTIMENT}

The opposition against EU can be culturally based reflecting concern with the establishment of a supranational European polity. Such a polity is establishing a new political community and threatens the autonomy of the established national political community creating the perception that the EU endangers the existence of their nation. The threat that the EU poses to long-established national identity, i.e. fear of denigration to national community, a common perceived cultural threat (McLaren, 2002, 2004) as well as economic national threat (Lucassen \& Lubbers, 2012) and political alienation (Ross, Mirowsky \& Pribesh, 2001) can generate opposition to and hostility toward the European project. Such an opposition to and an implicit or explicit hostility toward the EU we have defined as an anti-European sentiment, as an attitudinal construct encompassing fear of the loss of sovereignty, the loss of national identity, the loss of natural wealth, and negation of getting any benefit from the EU. In short, the anti-European sentiment or syndrome we defined in this researh as an explicit national threat perception and implicit economic threat perception posed by the EU integration, indicating the existence of a political distrust in European Union.

\section{POLITICAL CYNICISM}

Schyns and Koop (2007) found some common elements in definition of cynicism given in the literature such as a disbelief in the goodness of political actors and a general disdain toward politics. Specific for political cynicism are perceived immorality and perceived incompetence of political actors. Political cynicism thus entails denying the sincerity of the motives or actions of politicians. In our defining the construct of political cynicism we followed the definition offered by Schyns and Koop (2007) who argue that political cynicism as an individual's attitude consisting of beliefs and emotions indicating the presence of the immorality and incompetence of politicians, political institutions or political system as a whole. In other words, political cynicism indicates the existence of belief that politicians are wicked, selfish, corrupt and insencere. The construct of political cynicism, used in this research, was primarily defined in terms of perceived immorality of politicians following the perceived incompetence of the government. In such a defined political cynicism politicians are considered to be extremely selfish, 
corrupt and hypocrite, while the government is perceived as incompetent in a sense that it is not responsive to people's concerns, i. e. it does not take into account the interests of the people.

\section{NATIONAL SIEGE MENTALITY}

A few words about the concept of siege mentality, firstly introduced by Bar-Tal (1986) and labeled the Massada syndrome. The political-psychological meaning of the concept of siege mentality was lately defined as ,,a mental state in which members of a group hold a central belief that the rest of the world has highly negative behavioral intentions toward them" (Bar-Tal \& Antebi, 1992a, p. 634). Namely, siege mentality belief ,,refers to the perception by group members that the outgroups have intentions to do wrong or inflict harm on their group" (Bar-Tal \& Antebi, 1992b, p. 251). In other words, siege mentality implies the belief that a nation is standing alone against hostile world and that there is a threat to the group existence and that a nation cannot expect help from anyone in time of need. The operationalization of the construct of siege mentality, used in our reserach, was somewhat more specific than it is operationalised in General Siege Mentality Scale (GSMS) developed by Bar-Tal \& Antebi (1992a) and constructed on the basis of the conception of Masada Syndrome presented by BarTal (1986). However, the main political-psychological core was retained. The concept of siege mentality used in this research was primarily defined in terms of perceived national threat, that is why it is labeled national siege mentality. It is indicating the existence of negative intentions of the world against one's nation and readiness to use all means for self-defense including even the force to deter enemies from their attack, and negative political expectations from neighboring countries.

The main aim of this research was to find out whether an attitudinal constructs labeled political cynicism and national siege mentality have significant effects on the internalization of anti-European sentiment. Since political cynicism, anti-European sentiment, and national siege mentality could be considered in terms of political distrust (Goldfarb, 1991; Hart, 1978; Morris \& Klesner, 2010; Skinner, 2010; or Vujčić, 1999, 2008) and in terms of perceived threat (Jost \& Napier 2012; Šram, 2006, 2007, $200 \mathrm{gb}$ ), we proposed the existence of the distrust-threat model of political hostility that could help explain the interaction among political cynicism, national siege mentality, and anti-European sentiment. Namely, we assumed the existence of an underlying political cognitive and motivational processes within proposed political distrust-threat model. We assumed that political distrust as well as perceived threat are dynamic concepts that can be understood in two time projections: in a ,retrospective evaluation of events and a prospective assessment, which determine expectations of negative outcomes with a certain degree of conviction" (Bertsou, 2014, p. 2). From such a dynamic perspective that implies retrospective evaluation of the past events and prospective assessment of the future events anticipating bad social, political or individual events, we could uderstand and explain mutual relations among the latent variables investigated.

\subsection{METHOD}

\section{SUBJECTS AND PROCEDURE}

The data reported here were obtained by standard survey methods on a sample of adult population $(\mathrm{N}=553)$. The socio-demographic characteristic of the sample is presented in Table 1. As we can see, the sample was skewed toward above-average educational attainments because such a research requires an adequate literacy of respondents. This research report is a part of much larger investigation from the field of political sciences and social psychology carried out in the autumn of 2013. The self-report questionnaires of over 500 manifest variables were administered to respondents in their own homes by the trained interviewers. The respondents were asked to fill the questionnaires by themselves. The filled questionnaires were picked up by the interviewers the other day. We found statistically significant, but weak correlation between age groups and school attainment (the oldest group of respondents has more often elementary school, while the youngest group has more often a university degree). 
Table 1: Socio-demographic characteristics of the sample

\begin{tabular}{|c|c|}
\hline Variable & Per cent \\
\hline \multicolumn{2}{|l|}{ Gender } \\
\hline Male & 46.5 \\
\hline Female & 53.5 \\
\hline \multicolumn{2}{|l|}{ Age groups } \\
\hline 30 years or lower & 21.8 \\
\hline $31-45$ & $35 \cdot 5$ \\
\hline $46-60$ & 27.6 \\
\hline 61 or higher & 15.1 \\
\hline \multicolumn{2}{|l|}{ School attainment } \\
\hline Elementary school & 11.4 \\
\hline $\begin{array}{l}\text { Vocational school for skilled workers } \\
\text { (three years) }\end{array}$ & 22.1 \\
\hline $\begin{array}{l}\text { Secondary school } \\
\text { (four years) }\end{array}$ & 42.1 \\
\hline College & 12.2 \\
\hline University degree & 12.2 \\
\hline
\end{tabular}

Table 2: Correlations between the socio-demographic variables within the total sample

$\begin{array}{lrrr}\text { Variable } & 1 & 2 & 3 \\ 1 \text { Gender } & 1.00 & & 1.00 \\ 2 \text { Age groups } & -0.02 & -0.02 * * * & 1.00 \\ 3 \text { School attainment } & -0.06 & & \\ * * * p<.01 & & & \end{array}$

\section{MEASURE INSTRUMENTS}

Three measure instruments were applied in this research: (1) anti-European sentiment, (2) political cynicism, and (3) national siege mentality. The responses of these self-report scales rated on a 5-point Likert scale from: (1) strongly disagree to (5) strongly agree. This study integrates the two-step model building in structural equation model (SEM). In the first step, measurement models for all latent variables are estimated. Maximum likelihood confirmatory factor analysis (CFA) was performed for testing validity of the instruments applied in the study, using the LISREL 8.52 program. Namely, CFA provides a powerful tool for evaluating the validity of hypotheses about a scale's structure. In the second model building step, the structural part of the SEM was estimated. These structural part specified the relationships between the exogenous (independent) latent variables (i.e. political cynicism, and national siege mentality) and endogenous (dependent) latent variable. The following fit indices were used in assessing model fits: Although we report the chi-square statistics, we did not expect them to indicate a good fit because chi-square is heavily influenced by sample size and is therefore an inappropriately strict test of model fit (Kline, 2011). However, the value of the normed version of the chi-sqare test statistic (chi-square/df) was used in structural equation modeling indicating the goodness-of-fit (the normed version of the chi-square test in the range of 2.0 to 5.0 are acceptable, with lower values indicating better fit). Acceptable threshold level for RMSEA (Root Mean Square Error of Aproximation) is a value less than 0.07 (Steiger, 2007), for SRMR (standradized version of of the Root Mean Square Residual) threshold value is less than 0.08 (Hu \& Benter, 1999), for CFI (Comparative Fit Index) and NNFI (Non-Normed Fit Index) threshold values are greater than 0.95 (Sharma et al., 2005).

Anti-European sentiment. The four-item scale was constructed on the basis of the scale of anti-western political orientation developed by Šram $(2001,2007)$. CFA yielded unifactorial solution indicating that a measurement model has overall fit (RMSEA $=0.07, \mathrm{SRMR}=0.01, \mathrm{CFI}=1.00, \mathrm{NNFI}=0.99$ ). The chi-squared test for goodness-of-fit is statistically significant (Chi-square $=14.68, \mathrm{df}=2, \mathrm{p}<0.01$ ). The latent structure of anti-European sentiment was defined by the following indicators (factor loadings for each individual indicator are enclosed in brackets): 1 . The European Union will completely ruin our state sovereignity 
(0.86); 2. The EU will not bring any benefit to our country (0.81); 3. The EU will destroy our national identity (0.88); 4 . The EU will ruin our natural wealth (0.87).

Political cynicism. The four-item scale was constructed on the basis of conceptions of both political cynicism (Cappella \& Janieson, 1997) and political mistrust and alienation (Mishler \& Rose, 1997; Šram, 2009a). CFA yielded unifactorial solution indicating that a measurement model has overall fit (RMSEA $=0.07, \mathrm{SRMR}=0.01, \mathrm{CFI}=0.99, \mathrm{NNFI}=0.98$ ). The chi-squared test for goodness-of-fit is statistically significant (Chi-square $=14.32, \mathrm{df}=2, \mathrm{p}<0.01$ ): The latent structure of political cynicism was defined by the following indicators: 1. Politicians care only about their own interests and benefits (0.70); 2. Our government does not take into account the interests of the people (0.79); 3 . It is easy to bribe a majority of our politicians (0.83); 4 . A great majority of our politicians are hypocrites (0.73).

National siege mentality. The four-item scale was constructed on the basis of the conception of siege mentality developed by Bar-Tal and Antebi (1992a, 1992b) and on the concept of national siege mentality developed by Šram (2009b). CFA yielded unifactorial solution indicating that a measurement model has overall fit (RMSEA $=0.03, \mathrm{SRMR}=0.01, \mathrm{CFI}=1.00, \mathrm{NNFI}=0.99$ ). The chi-squared test for goodness-of-fit is statistically not significant (Chi-square $=4.64, \mathrm{df}=2, \mathrm{p}>0.05$ ). The latent structure was defined by the following indicators: 1 . Our existence is the end which justifies the means; 2 . The whole world is against us; 3 . Only demonstration of force will deter our enemies from attacking us; 4 . When neighboring countries get in conflicts, we will often be blamed for.

Composite variables of anti-European sentiment, political cynicism, and national siege mentality were also computed. Since all the indicators contribute strongly to the measurements of the latent variables being constructed, calculation of composite variables were reasonably justified. Namely, one-factor models, obtained by the confirmatory factor analysis, minimizes measurement error in the indicators contributing to each scale (Rowe, 2006). Descriptive statistics of the measures, are presented in Table 3. Taken with the skewness and kurtosis statistics, these results idicate that the storage scores are normaly distributed. Namely, as a rule of thumb, skewness and kurtosis values within the range from +2 to -2 are generally consider normal (Lomax \& Hahs-Vaughn, 2012). Having in mind that the measures consisted of only four items we can see that all the measures are internally consistent and reliable. The magnitude of intercorelations among composite variables within the total sample might indicate the existence of the latent variable underlying all three measures.

Table 3: Descriptive statistics of the measures (means, standard deviations, skewness and kurtosis, Cronbach's alphas) and correlations among them

\begin{tabular}{|c|c|c|c|c|c|c|c|c|}
\hline & M & SD & Skew & Kurtosis & $\begin{array}{r}\text { Cronbach's } \\
\text { Alpha }\end{array}$ & 1 & 2 & 3 \\
\hline 1 Anti-Europan sentiment & 13.0 & 4.6 & -0.22 & -0.80 & 0.91 & 1.00 & & \\
\hline 2 Political cynicism & 15.1 & 3.7 & -0.53 & -0.39 & 0.85 & $0.46 * * *$ & 1.00 & \\
\hline 3 National siege mentality & 10.8 & 63 & 0.17 & -0.62 & 0.70 & $0.40 * * *$ & $0.18 * *$ & 1.00 \\
\hline \multicolumn{9}{|c|}{$* * p<0.01, * * * p<0.001$} \\
\hline
\end{tabular}

\subsection{RESULTS}

Structural models for prediction an anti-European sentiment was developed and evaluated by using full information maximum likelihood estimates obtained from LISREL 8.52 program. Structural equation model was used to test the theorethical model that both political cynicism and national siege mentality as subtypes of political mistrust and perceived threat would effect anti-European sentiment. Structural equation model (Figure 1) indicated also good fit indices (RMSEA $=0.07, \mathrm{NNFI}=0.97, \mathrm{CFI}=0.97$, $\mathrm{SRMR}=0.05)$. The value of the normed version of chi-square test statistic is acceptable and indicates a good fit (chi-square/df=3.79). Both exogenous or independent variables political cynicism ( 0.44$)$ and national siege mentality (0.40) have proved to be significant predictors of anti-European sentiment. About 43 per cent of the variance can be explained by the structural model. 
Figure 1: Structural equation model of the effects of political cynicism and national siege mentality on anti-Europen sentiment

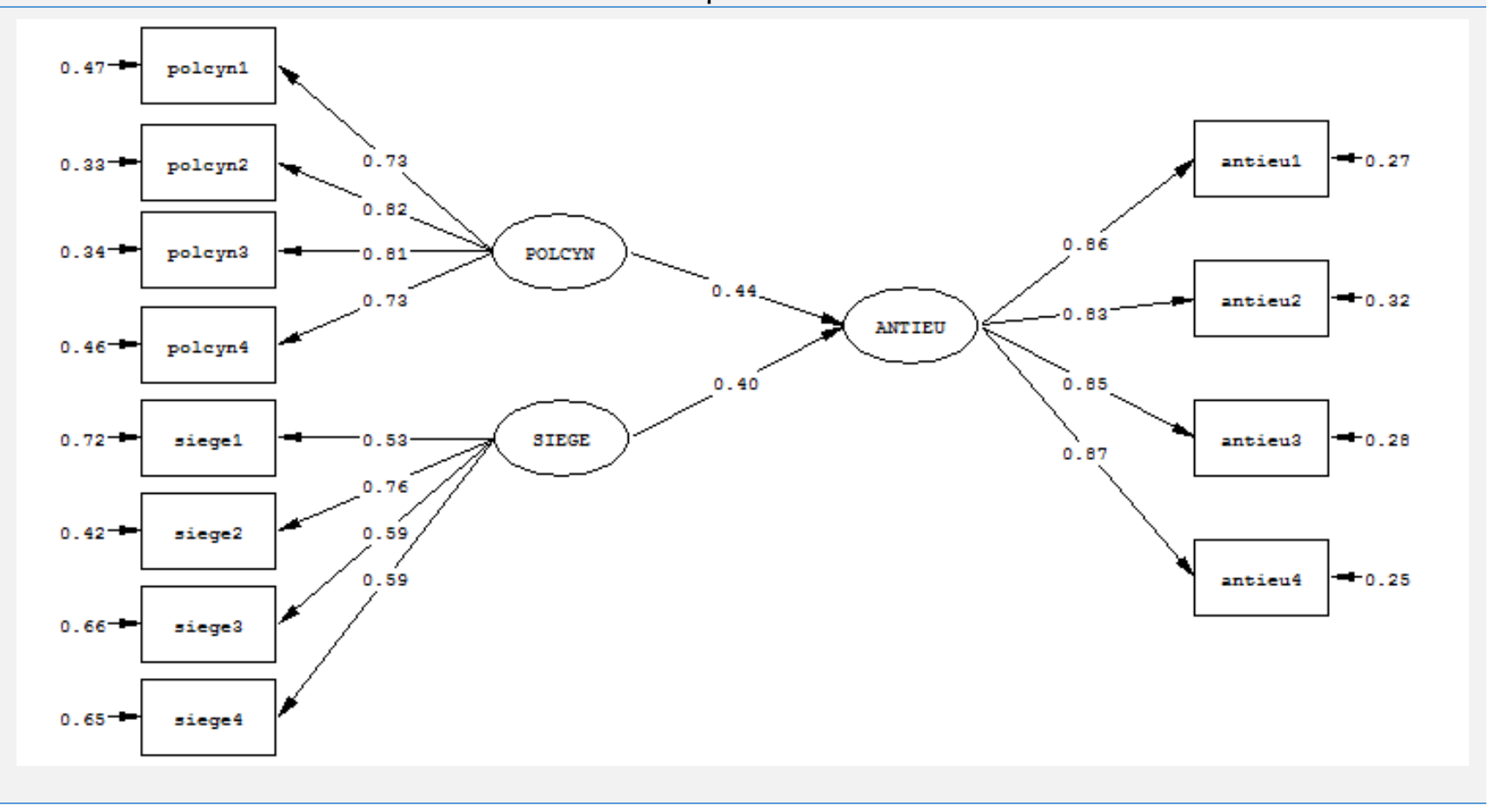

\subsection{DISCUSSION}

The results of structural equation modeling confirmed hypothesis that political cynicism and national siege mentality have significatn effects on the internalization of anti-European sentiment. Taking into account political-psychological meaning of attitudinal constructs investigated and its established relationships, we can conclude that there is, at least to a certain degree, the existence of an underlying similar political cognitive and motivational processes. Distrust in politicians and government as a whole, perceiving politicians as immoral and corrupt (Schyns \& Koop, 2007) who violate „prescriptive standards for their behavior" (Schwartz, 1974, p. 189), perceived negative and hostile intentions of other nations and states against one's nation, and mental readiness to use force to deter enemies from their attack (Bar-Tal and Antebi 1992a) are underlying anti-European sentiment. This political-attitudinal construct encompassing the existence of perceived threat to national sovereignty, to national identity and to national ecological system posed by the European Union, and the expression of a strong doubt that the country can get any benefit from the EU in general. A somewhat deeper insight into politicalpsychological meaning of political cynicism, national siege mentality, and anti-European sentiment may allow these attitudinal constructs be treated as a mixture of cognitive and affective evaluations consisting of specific political conviction.

Anti-European sentiment manifests diverse nature of hostility toward European integration perceiving the EU as a threat to nation's values, culture and identity (Crepsy \& Verschueren, 2009; Krouwel \& Abst, 2007), indicating the existence of national threat perception. It is obvious that EU as „supranational polity that exerts political authority over its citizens" and as a ,part of system of multilevel governance that encompasses national politics" (Hooghe \& Marks, 2005, p. 436) may be the saurce of national threat perception. Such perceived national threat that correspods to an attitudinal dimension toward the EU reflects an emotional response toward the EU (Boomgaarden et al., 2011). The EU poses political, cultural and economic threat that generates an overall implicit or explicit hostility toward European integration (McLaren, 2002, 2004; Lucassen \& Lubbers, 2012; Ross, Mirowsky \& Pribesh, 2001). 
Since political cynicism is the concept often equated with political distrust (Citrin \& Luks, 2001; Koch, 2003; Pattyn, Van Hiel, Dhont \& Onraet, 2012), it is reasonable than to place it within the realm of political distrust concepts based on the perceived immorality and perceived incompetence of political actors. However, political cynicism entails more negative connotation and emotions (Eisinger, 2000) and consists of anger and disgust with politics, where anger and hostility is ,endemic part of the political psyche" (Dekker \& Meijerink, 2012, p. 33) Political cynicism can surely be the threat to democracy, undermining, as Goldfarb (1991) says, the capacity to think about society's strength and weaknesses.

Bar-Tal and Antebi (1992b) argue that siege mentality as a belief in the cognitive reportoire is result of perceived experiences and of educational, cultural, political and social mechanism that maintain it. Very often happens that the nations that had been in war conflicts fixate on the past fear. This fear is grounded on the remembered threats in the past and past memorized experiences (Bar-Tal, 2001). Certainly the war conflics between Croats and Serbs, led on the territory of Croatia for its independance in the gos last century, implied the conflicts that inflicted ,severe negative experiences such as threat, stress, pain, exhaustion, grief, traumas, misery, hardship, and cost, both in life and material terms. In this cognitive-affective repertoire, societal beliefs are the basic components of collective memories and ethos of conflict" (Bar-Tal, 2007, p. 1434). The presence and development of siege mentality generated from such a past fear and war traumas became a kind of central societal belief that ,provide the prism through which society members will view the world and relate to it. This prism not only organizes society's cognitive outlook or directs intentional forms of action, but also sets its collective emotional orientation" (Bar-Tal, 2001, p. 606). It is hardly possible to overlook that personal hostility, collective enmity and political distrust toward other nations are undelying national siege mentality and perception of threat.

The analysis of the contents and political-psychological meaning of the investigated attitudinal construsts revealed that all of them encompass both political distrust and perceived threat. Thus, political cynicism indicates political distrust toward politicians and perceived threat posed the domestic political system that is to a very small degree responsive to voters' concerns (Citrin \& Luks, 2000; Erber \& Lau, 1990; Newton, 2006). National siege mentality indicates political distrust toward other nationstates and perceived national security threat posed by the outside enemies. Anti-European sentiment indicates implicitily political distrust toward the European integration processes/institutions and pereceived cultural and economic threat. What all three political attitudinal constructs have in common is an underlying political hostility that can be developed and socialized on an individual and collective level. Namely, political distrust and perceived threat against a collective can also represents a personal political distrust and threat (Rousseau \& Garcia-Retamero, 2007). For instance, Croatian citizens may express a collective political distrust toward the EU integrations and view the EU as a collective cultural and economic threat against its nation, on one hand, and a personal political distrust towards the values of EU and express threat against his/her personal values and beliefs, on the other.

The intercorrelations among the composite variables of political cynicism, national siege mentality, and anti-European sentiment were of a such magnitude (see table 3) that indicated the existence of latent variable underlying all three composite measures. Exploratory factor analysis, using principal components, extracted one component explaining 56.67 per cent of the variance. The factor loadings ranged between 0.66 and 0.85 . Factor analysis revealed an underlying latent variables in the samples investigated. This factorially exctracted variable was labeled political distrust and threat perception. We can see that such a distrust-threat perception underlys political hostility toward both domestic and foreign actors of polity. In other words, anti-European may be treated as a component of a broader hostile political attitudinal pattern that indicates the existence of a certain type of political alienation or even as a pattern of a potentially conservative or extreme ideology (Abrams, 2012; Jost and Napier, 2012; Malka, Soto, Inzlicht \& Lelkes, 2014). Thus, an anti-European sentiment cannot be explained and understood only within the realm of economic cost/benefit calculations, war legacies in former Yugoslavia and the roles of political parties generating an anti-European sentiment, but also within the distrust-threat model of political hostility, as we suggest in this paper. Namely, cognitive and 
motivational processes underlying the distrust-threat model of political hostility, whose component is ant-European sentiment, serves to reduce uncertainty and anxiety about both the individual and collective future. In other words, such a distrust-threat model of political hostility predicted that the psychological appeal of attitudes, comprising the structure of anti-European sentiment, is strengthened whenever needs to reduce colective uncertainty, political distrust and threat are elevated (Jost and Napier, 2012). In this way anti-European sentiment might be considered the consequence of ,selfprotective, defensive motivational needs for control and security“ (Duckitt, 2001, p.85), showing a model of cognitive (perceived threat) and motivational (epistemic and existential nees for security) underpinning of this political orientation, that can be associated with political conservatism or ideological extremity (Abrams, 2012; Jost et al., 2007) or with historical revisionism and political reevaluation of former communist (totalitarian) regime that conferred existential security (Šram, 2015). In short, anti-European sentient can be treated, just like an ideological pattern, as ,,motivated social cognition" (Jost and Amodio, 2012, p. 57) which holds the needs to manage political distrust and perceived threats to the self, to the group and to the system and nation posed by internal and external political actors and forces. It is no need to especially emphasize that such a distrust-threat perception underlying political hostility have negative effects on community, democracy, security, economic prosperity, on society itself (Putnam, 1995; Sullivan and Transue, 1999; Zeineddine and Pratto, 2014), and even on the people's mental health (Swami and Furnham, 2014; Sullivan and Transue, 1999). We speculate that similar distrust-threat models of political hostility, of which an anti-European sentiment is just a part, would be obtained in other former communist countries.

\section{REFERENCES}

Abrams, D., (2012). Extremism is Normal: The Role of Deviance and Uncertainty in Shaping Groups and Society. In Michael A. Hogg \& Danielle L. Blaylock (eds.), Extremisim and the Psychology of Uncertainty (pp.36-54). Chichester, West Sussex, UK: Wiley-Blackwell.

Bar-Tal, D., (1986). The Masada Syndrome: A Case of Central Belief. In Norman A. Milgram (Ed.), Stress and Coping in Time of War: Generalizations from the Israeli Experience (pp. 32-51). New York: Brunner/Mazel Psychosocial Stress Series, Vol 7.

Bar-Tal, D., (2001). Why Does Fear Override Hope in Societies Engulfed by Intractable Conflict, as it Does in the Israeli Society. Political Psychology, 22 (3), 601-627.

Bar-Tal, D., (2007). Sociopsychological Foundations of Intractable Conflicts. American Behavioral Scientist, 50 (11), 1430-1453.

Bar-Tal, D., \& Antebi, D., (1992a). Beliefs About Negative Intentions of the World: A Study of the Israeli Siege Mentality. Political Psychology, 13 (4), 633-645.

Bar-Tal, Daniel \& Antebi, D., (1992b). Siege Mentality in Israel. International Journal of Intercultural Relation, 16 (3), 251-275.

Bersou, E., (2014). Disentagling Political Distrust: What Do Citizens Mean and Think When Claiming to Distrust Political Institutions and Politicians. Paper presented at the Midwest Political Science Association 73rd Annual Conference, Chicago, April 2004.

Boomgaarden, H. G., Schuck A. R.T., Elenbass, M., \& de Vreese, C.H. (2011). Mapping EU Attitudes: Conceptual and Empirical Dimensions of Euroscepticism and EU Support. European Union Politics, $12(2), 241-266$.

Cappella, J. N. \& Janieson, K.H., (1997). Spiral of Cynicism: The Press and the Public Good. New York: Oxford University Press.

Citrin, J. \& Lux, S., (2001). Political Trust Revisited: Deja Vu All Over Again? In John R. Hibbing \& Elizabeth Theis-Morse (Eds.), What is it About Government that Americans Dislike? (pp. 9-27). New York: Cambridge University Press.

Crepsy, A.,\& Verschueren, N., (2009). From Euroscepticism to Resistance to European Integration: An Interdisciplinary Perspective. Perspectives on European Politics and Society, 10 (3), 377-393.

Dekker, H., \& Meijerink, E., (2012). Political Cynicism: Conceptualization, Operationalization, and Explanation. Politics, Culture and Society, 3 (1-2), 33-48. 
Duckitt, J., (2001). A Dual Process Cognitive-Motivation Theory of Ideology and Prejudice. Advances in Experimental Psychology, 33, 41-113.

Eisinger, R. M. (2000). Questioning Cynicism. Society, 37 (5), 55-60.

Erber, R. \& Lau, R.R., (1990). Political Cynicism Revisited: An Information-Processing Reconciliation of Policy-Based and Incumbency.Based Interpretations of Changes. American Journal of Political Science, 34 (1), 236-253.

Gabel, M. \& Palmer,m H.D., (1995). Understanding Variation in Public Support for European Integration. European Journal of Political Research, 27 (1), 3-19.

Glaurdić, J. \& Vuković V.,(2015). Prosperity and Peace: Economic Interests and War Legacy in Croatia's EU Referendum Vote. European Union Politics, online first, 27 April 2015.

Goldfarb, J. C. (1991). The Cynical Society: The Culture of Politics and the Politics of Culture in American Life. Chicago: The University of Chicago Press.

Hart, V. (1978). Distrust and Democracy: Political Distrust in Britain and America. Cambridge: Cambridge University Press.

Hartleb, F. (2012). European Project in Danger? Understanding Precisely the Phenomena „Euroscepticism, Populism and Extremism“ in Times of Crisis. Review of European Studies, 4 (5), 4563.

Hooghe, L. \& Marks G.,(2005). Calculation, Community and Cues: Public Ipinion on European Integration. European Union Politics, 6 (4), 419-443.

Hu, Li-tze \& Bentler, P.M., (1999). Cutoff Criteria for Fit Indices in Covariance Structural Analysis: Conventional Criteria Versus New Alternatives. Structural Equation Modeling: A Multidisciplinary Journal, 6 (1), 1-55.

Jost, J. T. \&. Amodio, D.M., (2012). Political Ideology as Motivated Social Cognition: Behavioral and Neuroscientific Evidence. Motivation and Emotion, 36 (1), 55-64.

Jost, J. T, Federico, C. M. \& Napier, J.L., (2009). Political Ideology: Its Structure, Functions, and Elective Affinities. Annual Review of Psychology, Vol. 60, 307-337.

Jost, J. T. \& Napier, J.L., (2012). The Uncertainty-Threat Model of Political Conservatism. In Michael A. Hoog \& Danielle L. Blaylock (Eds.), Extremism and Psychology of Uncertainty (pp. 90-111). Chichester, West Sussex, UK: Wiley-Blackwell.

Jost, J. T., Napier, J.L.,, Thorisdottir, H., Gosling, SD., Palfai, TP., \& Ostafin B., (2007). Are Needs to Manage Uncertainty and Threat Associated with Political Conservatism or Ideological Extremity? Personality and Social Psychology Bulletin, 33 (7), 989-1007.

Kline, R. B. (2011). Principles and Practice of Structural Equation Modeling (3rd Ed.). New York: The Guilford Press.

Koch, J. W. (2003). Political Cynicism and Third Party Support in Amercan Presidential Elections. American Politics Research, 31 (1), 48-65.

Lomax, R. G. \& Debbie L. Hahs-Vaughn (2012). An Introduction to Statistical Concepts (3rd Ed.). New York: Taylor \& Francis Group.

Lucassen, G. \& M. Lubbers (2012). Who Fears What? Explaining Far-Right-Wing Preferences in Europe by Distinguishing Perceived Cultural and Economic Ethnic Threats. Comparative Political Studies, 45 (5), 547-574.

Malka, A., C. Soto, Michael Inzlich \& Yphtach Lelkes (2014). Do Needs for Security and Certainty Predict Cultural and Economic Conservatism? A Cross-National Analyis. Journal of Personality and Social Psychology, 106 (6), 1031-1051.

McLaren, L.M. (2002). Public Support for the European Union: Cost/Benefit Analysis of Perceived Cultural Threat. Journal of Politics, 64 (2), 551-566.

McLaren, L. M. (2004). Opposition to European Integration and Fear of Loss of National Identity: Debunking a Basic Assumption Regarding Hostility to the Integration Project. European Journal of Political Reserach, 43 (6), 895-912.

Mishler, W. \& Rose R. (1997). Trust, Distrust and Skepticism: Popular Evaluation of Civil and Political Institutions in Post-Communist Societies. The Journal of Politics, 59 (2), 418-451.

Mishler, W. \& Rose R. (2001). What are the origins of Political Trust? Testing Institutional and Cultural Theories in Post-communist Societies. Comparative Political Studies, 34 (1), 30-62. 
Morris, S. \& Klesner JL., (2010). Corruption and Trust: Theorethical Considerations and Evidence from Mexico. Comparative Political Studies, 43 (10), 1258-1285.

Newton, K. (2006). May the Weak Force Be With You: The Power of the Mass Media in Modern Politics. European Journal of Political Research, 45 (2), 209-324.

Pattyn, S., Hiel, AV., Dhont K., \& Onraet E., (2012). Stripping the Political Cynic: A Psychological Exploration of the Concept of Political Cynicism. European Journal of Personality, 26 (6), 566-579.

Putnam, R. D. (1995). Bowling Alone: America's Declining Social Capital. Journal of Democracy, 6 (1), 6578.

Ross, C. E., John Mirowsky \& Shana Pribesh (2001). Powelessness and Amplification of Threat: Neighborhood Disadvantage, Disorder, and Mistrust. American Sociological Review, 66 (4), 568-591.

Rousseau, D. L. \& Garcia-Retamero R., (2007). Identity, Power, and Threat Perception. Journal of Conflict Resolution, 51 (5), 744-771.

Schwartz, S. K. (1975). Patterns of Cynicism: Differential Political Socialization among Adolescentes. In David Schwartz \& Sandra Kenyon Schwartz (Eds.), New Directions in Political Socialization (pp. 188202). New York: Free Press.

Schyns, P. \& Koop C. (2007). Political Cynicism: Characteristics and Consequences of a Growing Phenomenon. Paper presented at the 4th General ECPR Conference, Pisa, Italy, 6-8 September, 2007.

Sharma, S., Mukherje, S., Kumar A., \& Dillon WR., (2005). A Simulation Study to Investigate the Use of Cutoff Values for Assessing Model Fit in Covariance Structure Models. Journal of Business Research, 58 (7), 935-943.

Skinner, M. (2010). Political Culture, Values and Economic Utility: A Different Perspective on Norwegian Party-based Euroscepticism. Journal of Contemporary European Research, 6 (3), 299-315.

Steiger, J. H. (2007). Understanding the Limitations of Gloval Fit Assessment in Structural Equation Modeling. Personality and Individual Differences, 42 (5), 893-898.

Sullivan, J. L. \& Transue JE., (1999). The Psychological Underpinning of Democracy: A Selective Review of Reserach on Political tolerance, Interpersonal Trust, and Social Capital. Annual Review of Psychology, 50, 625-650.

Swami, V. \& Adrian Furnham (2014). Political Paranoia and Conspiracy Theories. In Jan-Willem Van Prooijen \& Paul A.M. Van Lange (Eds.), Power, Politics and Paranoia: Why People Are Suspicious of Their Leaders (pp. 218-236). Cambridge: Cambridge University Press.

Šram, Z. (2001). Antizapadna orijentacija kao komponenta šire ideologijske matrice: slučaj Vojvodine (Anti-Western Orientation as Component of a Broader Ideological Pattern: The Case of Vojvodina). Politička misao (Croatian Political Science Review), 38 (2), 91-110.

Šram, Z. (2006). Socijalni stavovi i osobine ličnosti kao komponente političke kulture (Social Attitudes and Personality Traits as the Components of Political Culture). U: S. Mihailović (ur.), Pet godina tranzicije u Srbiji II (Five Years of Transition and Serbia II) (str. 200-218). Beograd: Socijaldemokratski klub i Fondacija Friedrich Ebert.

Šram, Z. (2007). Anomija, depresivnost i antizapadna orijentcija (Anomie, Depressiveness, and AntiWestern Orientation). Revija za sociologiju (Sociological Review), 38 (3-4), $103-118$.

Šram, Z. (2009a), Socijalna alijenacija bunjevačkih Hrvata u Vojvodini (Social Alienation of the Croatian Bunjevci in Vojvodina). Sociologija i prostor (Sociology and Space), 47 (1), 3-25.

Šram, Z. (2009b). Mentalitet nacionalnog opsadnog stanja i predsjednički izbori 2008. u Srbiji (National Siege Mentality and the 2008 Presidential Elections in Serbia). Revija za sociologiju (Sociologica Review), 40 (1-2), 23-52.

Šram, Z. (2015), National Threat Perception, Dominance-Submissive Authoritarian Syndrome and Totalitarian Socialist Ideology (in press).

Vujčić, V. (1999). Politička kultura: politička potpora (legitimacija, povjerenje, identitet) (Political Support for Political system). Politička misao (Croatian Political Science Review), 36 (3), 151-179.

Vujčić, V. (2008). Kultura i politika (Culture and Politics). Zagreb: Politička kultura.

Zeineddine, Fouad Bou \& Felicia Pratto (2014). Political Distrust: The Seed and Fruit of Popular Empowerment. In Jan-Willem Van Prooijen \& Paul A.M. Van Lange (Eds.), Power, Politics and Paranoia: Why People Are Suspicious of Their Leaders (pp. 106-129). Cambridge: Cambridge University Press. 